\title{
Effect of different icing conditions on lipid damage development in chilled horse mackerel (Trachurus trachurus) muscle
}

\author{
By M. Sanjuás-Rey ${ }^{1}$, J. Barros-Velázquez ${ }^{1}$ and S.P. Aubourg ${ }^{2^{\star}}$ \\ ${ }^{1}$ Department of Analytical Chemistry, Nutrition and Food Science, School of Veterinary Sciences, University \\ of Santiago de Compostela, Lugo, Spain. \\ ${ }^{2}$ Department of Food Technology. Instituto de Investigaciones Marinas (IIM-CSIC), Vigo, Spain. \\ ( Corresponding author: saubourg@iim.csic.es)
}

\begin{abstract}
RESUMEN
Efecto de distintas condiciones de refrigeración sobre la alteración lipídica en músculo de jurel (Trachurus trachurus).

Se estudió el empleo de hielo conteniendo una mezcla de ácidos orgánicos naturales (cítrico, ascórbico, láctico) como método de refrigeración en jurel (Trachurus trachurus). Para ello, se aplicó hielo incluyendo dos concentraciones $(0.005$ y $0.020 \%$; p/v) de cada ácido (condiciones P-1 y P-2, respectivamente). Se estudiaron los efectos producidos sobre el desarrollo de la alteración lipídica en el músculo de pescado conservado durante 13 días; asimismo, se realizaron análisis químicos complementarios de calidad y de aceptación sensorial. Como resultado de la presencia de los ácidos, se observó un pequeño efecto inhibidor de la formación de peróxidos y de sustancias reactivas con ácido tiobarbitúrico. Asimismo, las muestras correspondientes al tratamiento P-2 reflejaron un tiempo de vida útil mayor que las pertenecientes a las condiciones P-1 y control. La presencia de ácidos en el hielo no produjo diferencias en la degradación de nucleótidos ni en la formación de ácidos grasos libres.
\end{abstract}

PALABRAS CLAVE: Ascórbico - Cítrico - Láctico - Lípidos - Oxidación - Refrigeración - Trachurus trachurus.

\section{SUMMARY}

Effect of different icing conditions on lipid damage development in chilled horse mackerel (Trachurus trachurus) muscle.

This study was aimed at investigating the effect of including a mixture of natural organic acids (citric, ascorbic and lactic) in the icing medium employed during the chilled storage of horse mackerel (Trachurus trachurus). To this end, two aqueous solutions including $0.005 \%$ and $0.020 \%$ $(\mathrm{w} / \mathrm{v})$ of each acid (P-1 and P-2 conditions, respectively) were employed as icing systems. The effects on lipid damage development in fish muscle were monitored for up to a 13day storage period; complementary chemical quality and sensory acceptance analyses were carried out. According to peroxide and thiobarbituric acid reactive substance assessment, a slight inhibitory effect was concluded as a result of the acid mixture present in the chilling medium. At the same time, P-2-treated fish showed a longer shelf life than their counterparts belonging to $\mathrm{P}-1$ and control conditions. No effect of the acid presence in the icing system could be outlined on the nucleotide degradation or the free fatty acid formation.

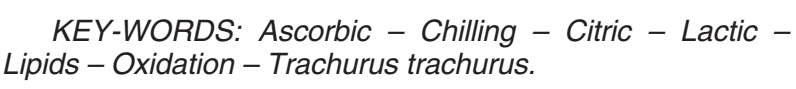

\section{INTRODUCTION}

Marine species deteriorate rapidly after death owing to the effect of a wide variety of biochemical and microbial degradation mechanisms (Whittle et al., 1990; Olafsdóttir et al., 1997). Marine lipids are known to be composed of highly unsaturated fatty acids that are prone to oxidation development, which leads to an important effect on fish quality loss (Aubourg, 1999; Chaouqy et al., 2008). Accordingly, the application of newer and more efficient refrigeration systems to the operations involved in fish handling and storage has drawn attention to enhancing the quality of commercial products. With this objective, a number of preservative strategies to be combined with flake ice chilling have been tested satisfactorily such as previous chemical and physical treatments (Toledo-Flores and Zall, 1992; Ashie et al, 1996) and packaging (Ozen and Floros, 2001; Sivertsvik et al., 2002); other strategies have included the replacement of flake ice with slurry ice (Lago et al., 2010; Aubourg et al., 2010) or chilled sea water (Slattery and Forrest, 2006).

Among previous chemical treatments for chilling storage, natural low molecular weight organic acids and their sodium salts have shown to represent a good choice because of their easy availability, low commercial cost and wide range of permitted concentrations for their use in both European and American administrations (Madrid et al., 1994; Giese, 1996). Thus, ascorbic and citric acids (AA and $C A$, respectively) are widely known for their role as chelators, acidulants in biological systems and synergists of primary antioxidants, so that a profitable effect on fish fillets (Badii and Howell, 2002; Kilinc et al., 2009; Pourashouri et al., 2009) and whole fish (Aubourg et al., 2004) has been observed. Further, lactic acid (LA) has been reported 
to be effective in suppressing Gram-negative bacteria, which are known to be the most important fish spoiler group; thus, LA pre-treatment has shown to be effective in preserving and extending shelf life in fish fillets (Kim et al., 1995; Metin et al., 2001; Erkan, 2003), coated fish (Gogus et al., 2006) and fish slices (Sallam, 2007).

Small pelagic fish species can constitute food products of great economic importance in many European countries (FAO, 2007a). Some of these species are captured in high proportions when their demand is relatively low, so that a large portion of their catches is underutilized and transformed into fish meal for animals. One such abundant mediumfat species in the Northeast Atlantic is horse mackerel (Trachurus trachurus) (FAO, 2007b). Great efforts have been made to enhance its shelf life in the frozen state as whole (Simeonidou et al., 1997; Aubourg and Ugliano, 2002; Lugasi et al., 2007), fillet (Simeonidou et al., 1997; Aubourg et al., 2004) or restructured (Sánchez-Alonso et al., 2007; Pazos et al., 2008; Eymard et al., 2010) fish products. Concerning the horse mackerel chilled storage under traditional flake ice conditions, an important quality loss has been observed relating to microbial, physical, chemical and sensory properties (Smith et al., 1980; Mendes, 1999; Aubourg, 2001; Shigemura et al., 2003). Therefore, alternative chilling methods have been attempted such as refrigerated sea water (Smith et al., 1980), liquid ice (Piñeiro et al., 2004) and previous irradiation (Mendes et al., 2005) to inhibit this quality loss.

The present work focuses on the search for appropriate technological treatments that may lengthen the shelf-life of whole horse mackerel traded as a chilled product. To this end, ice including different quantities of CA, AA and LA, was tested as a chilling system. The effects on lipid damage development in fish muscle were monitored for up to 13 days of chilled storage; complementary chemical quality and sensory acceptance analyses were also carried out.

\section{MATERIALS AND METHODS}

\subsection{Icing systems}

Aqueous solutions including two concentration values $(0.050 \%$ and $0.020 \%$, w/v) of each natural organic acid (CA, AA and LA) were prepared, packed in polythene bags and kept frozen at $-20^{\circ} \mathrm{C}$ until use. Traditional ice was prepared starting from water only that was packed and kept frozen in the same way as the ones including the organic acid mixtures. Before addition to individual fishes, the different ices were ground to obtain common flakes.

\subsection{Raw fish, processing and sampling}

Fresh horse mackerel (117 individuals) were caught near the Galician Atlantic coast (north western Spain) in Autumn 2010 and transported on ice to the laboratory. The length and weight of the fish specimens were included in the following ranges: 25$30 \mathrm{~cm}$ and $200-250 \mathrm{~g}$, respectively.

Upon arrival at the laboratory, nine individual fishes were separated and considered as starting raw fish (day 0). Three different groups (three individuals per group) were analyzed independently $(n=3)$. The remaining fish were divided into three batches (36 individuals in each batch). The first batch was placed in boxes and directly surrounded by ice prepared with the aqueous solution including $0.005 \%$ of each acid (preserved fish; P-1 condition). The second batch was placed in boxes and surrounded by ice prepared with the aqueous solution including $0.020 \%$ of each acid (preserved fish; P-2 condition). The remaining batch was placed in boxes and surrounded by traditional ice prepared with water only (control fish; C condition). In all batches, a 1:1 fish-to-ice ratio was employed. All batches were placed in a refrigerated room $\left(4^{\circ} \mathrm{C}\right)$. Boxes were allowed to drain and the ice was renewed when needed. Fish samples were taken for analysis on days 4, 7, 11 and 13. At each sampling point, nine individuals from each batch were taken for analysis, being classified into three groups (three individuals in each group) and were studied independently $(n=3)$.

\subsection{Lipid damage analysis}

Lipids were extracted from the fish white muscle according to the Bligh and Dyer (1959) method, employing a single-phase solubilization of the lipids using a chloroform-methanol (1:1) mixture. Quantification results were expressed as $\mathrm{g}$ lipid/ $100 \mathrm{~g}$ muscle.

The peroxide value (PV) was determined in the lipid extract by peroxide reduction with ferric thiocyanate, according to the Chapman and McKay (1949) method. Results were expressed as meq active oxygen/ kg lipids.

The thiobarbituric acid index (TBA-i) was determined according to Vyncke (1970). This method is based on the reaction between a trichloracetic acid extract of the fish muscle and thiobarbituric acid. The content of thiobarbituric acid reactive substances (TBARS) was spectrophotometrically measured at $532 \mathrm{~nm}$ and the results were expressed as $\mathrm{mg}$ malondialdehyde/ kg muscle.

The formation of fluorescent compounds was determined by measurements at $393 / 463 \mathrm{~nm}$ and $327 / 415 \mathrm{~nm}$ as described by Aubourg et al. (2004). The relative fluorescence (RF) was calculated as follows: $R F=F / F_{s t}$, where $F$ is the fluorescence measured at each excitation/ emission maximum, and $F_{s t}$ is the fluorescence intensity of a quinine sulphate solution $\left(1 \mu \mathrm{g} / \mathrm{mL}\right.$ in $\left.0.05 \mathrm{M} \mathrm{H}_{2} \mathrm{SO}_{4}\right)$ at the corresponding wavelength. The fluorescence ratio $(F R)$ was calculated as the ratio between the two $\mathrm{RF}$ values: $\mathrm{FR}=\mathrm{RF}_{393 / 463 \mathrm{~nm}} / \mathrm{RF}_{327 / 415 \mathrm{~nm}}$. The $\mathrm{FR}$ value was determined in the lipid fraction resulting from the fish muscle extraction (Bligh and Dyer, 1959). 
The free fatty acid (FFA) content was determined in the lipid extract of the fish muscle according to the Lowry and Tinsley (1976) method based on a complex formation with cupric acetate-pyridine followed by spectrophotometric $(715 \mathrm{~nm})$ assessment. Results were expressed as g FFA/kg muscle.

\subsection{Quality loss analysis by non-lipid chemical indexes}

Nucleotide degradation analysis was carried out starting from $6 \%$ perchloric acid extracts from the fish muscle according to previous research (Ryder, 1985). The analysis was performed using HPLC, with a Beckman device provided with the programmable solvent module 126, and the scanning detector module 167 connected to the System Gold software, version 8.1 (Beckman Coulter, London, UK). Separations were achieved on a reverse-phase Spherisorb ODS2 C18 $250 \times 4.60 \mathrm{~mm}$ column (Waters, Milford, MA, USA), with an internal particle diameter of $5 \mu \mathrm{m}$. Standard curves for adenosine 5'-triphosphate (ATP) and each compound involved in its degradation pathway, adenosine 5'-diphosphate (ADP), adenosine 5'-monophosphate (AMP), inosine 5'-monophosphate (IMP), inosine (INO) and hypoxanthine $(\mathrm{Hx})$, were constructed in the 0-1 mM range. Results obtained for each degradation compound were calculated as $\mathrm{mmol} /$ $\mathrm{kg}$ muscle. The $\mathrm{K}$ value was calculated according to the following concentration ratio:

$$
\begin{gathered}
\mathrm{K} \text { value }(\%)=100 \times(\mathrm{INO}+\mathrm{Hx}) / \\
(\mathrm{ATP}+\mathrm{ADP}+\mathrm{AMP}+\mathrm{IMP}+\mathrm{INO}+\mathrm{Hx})
\end{gathered}
$$

The evolution of $\mathrm{pH}$ values in fish muscle throughout storage time was determined by means of a 6-mm diameter insertion electrode (Crison, Barcelona, Spain).

\subsection{Sensory analysis}

A sensory analysis was conducted by a sensory panel consisting of five experienced judges, according to guidelines concerning fresh and refrigerated fish (Council Regulations, 1989). Panellists have been involved in sensory analysis of different kinds of fish foods for the last 10 years. Previous to the present experiment, a special training session was conducted on chilled horse mackerel.

Four categories were ranked: highest quality $(E)$, good quality (A), fair quality (B) and unacceptable quality $(C)$. Sensory assessment of the fish included the following parameters: eyes, gills, external odor, flesh odor (raw and cooked fish) and taste (cooked fish). At each sampling time, the fish muscle portions were presented to panellists in individual trays and were scored individually. The panel members shared samples tested.

\subsection{Statistical analysis}

Data corresponding to the three icing batches were subjected to one-way analysis of variance to assess significant $(p<0.05)$ differences among batches. The Statsoft (Statistica, version 6.0, 2001) software was used to explore the statistical significance of the results obtained, including multivariate contrasts and multiple comparisons by the Scheffe, Tukey and Kruskal-Wallis tests. A confidence interval at the $95 \%$ level was used in all cases.

\section{RESULTS AND DISCUSSION}

\subsection{Lipid oxidation development}

The lipid contents of fish white muscle ranged from 1.0 and $2.5 \%$. The differences observed may be attributed to fish-to-fish variation and not to icing conditions or storage time. The value range obtained corresponds to a medium-fat fish species and agrees with previous research on the same fish species (Aubourg, 2001; Losada et al., 2005).

Lipid oxidation development was assessed by means of the peroxide (primary oxidation), TBARS (secondary oxidation) and fluorescent compound (FR value; tertiary oxidation) formation.

The peroxide development showed a great increase in fish corresponding to control conditions in the 11-13-day period (Table 1); however, during such a period, PV remained under 7.0, a score for fish corresponding to both preserving icing conditions ( $\mathrm{P}-1$ and $\mathrm{P}-2)$. As a result, an inhibitory effect on peroxide formation could be concluded for the presence of the acid mixture in the icing system, while no effect of the acid content could be outlined.

TBARS formation led to fewer differences than in the case of the PV assessment (Table 1). However, some inhibitory effect $(p<0.05)$ could be concluded for the P-2 icing condition (days 4 and 13) and for the P-1 condition (day 13) as a result of the acid presence in the icing system. As for the PV analysis, an increasing TBARS content was observed with time in all types of processed fish.

Interaction compound formation between oxidized lipids and nucleophilic compounds (namely, proteinlike molecules; tertiary lipid oxidation) was assessed according to the fluorescence ratio (Table 2). This analysis showed some differences at earlier stages of the study (day 4 for P-2 condition and day 7 for P-1 condition) when compared to control fish; however, no differences $(p>0.05)$ could be found in the latest stages of the study (11-13-day period), when a higher effect on tertiary lipid oxidation compound would be expected to be present as a result of a higher primary and secondary lipid oxidation development (Table 1).

\subsection{Lipid hydrolysis development}

With regards to lipid hydrolysis development, no differences $(p>0.05)$ in FFA formation could be concluded as a result of the icing condition employed (Table 2). Indeed, their formation was found relatively low throughout the whole experiment when compared 
Table 1

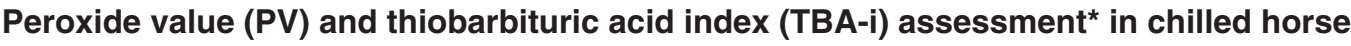
mackerel kept under different icing conditions ${ }^{\star *}$

\begin{tabular}{ccccccc}
\hline $\begin{array}{c}\text { Chilling } \\
\text { Time } \\
\text { (days) }\end{array}$ & \multicolumn{3}{c}{$\begin{array}{c}\text { Peroxide Value } \\
\text { (meq active oxygen/ kg lipids) }\end{array}$} & \multicolumn{3}{c}{$\begin{array}{c}\text { Thiobarbituric Acid Index } \\
\text { (mg malondialdehyde/ kg muscle) }\end{array}$} \\
\hline \multirow{2}{*}{4} & $\mathbf{C}$ & $\mathbf{P - 1}$ & $\mathbf{P - 2}$ & $\mathbf{C}$ & $\mathbf{P}-1$ & $\mathbf{P}-\mathbf{2}$ \\
& 2.46 & 2.72 & 2.36 & $0.62 \mathrm{~b}$ & $0.64 \mathrm{~b}$ & $0.30 \mathrm{a}$ \\
& $(0.78)$ & $(1.07)$ & $(1.11)$ & $(0.10)$ & $(0.13)$ & $(0.16)$ \\
7 & 4.61 & 3.95 & 4.35 & 0.65 & 0.72 & 0.59 \\
& $(1.94)$ & $(1.86)$ & $(1.01)$ & $(0.10)$ & $(0.23)$ & $(0.13)$ \\
11 & $10.63 \mathrm{~b}$ & $6.38 \mathrm{ab}$ & $6.70 \mathrm{a}$ & 1.08 & 0.99 & 0.98 \\
& $(1.92)$ & $(2.61)$ & $(1.61)$ & $(0.08)$ & $(0.17)$ & $(0.11)$ \\
13 & $14.07 \mathrm{~b}$ & $6.67 \mathrm{a}$ & $6.87 \mathrm{a}$ & $1.61 \mathrm{~b}$ & $1.37 \mathrm{a}$ & $1.22 \mathrm{a}$ \\
& $(2.35)$ & $(1.88)$ & $(2.32)$ & $(0.12)$ & $(0.10)$ & $(0.14)$ \\
\hline
\end{tabular}

* Mean values of three independent determinations $(n=3)$; standard deviations are indicated in brackets.

Starting fish values: $1.34 \pm 0.52(P V)$ and $0.30 \pm 0.04$ (TBA-i). For each parameter and for each chilling time, mean values followed by different letters $(a, b)$ indicate significant $(p<0.05)$ differences as a result of the icing condition.

** Abbreviations of icing conditions: P-1 (ice including $0.005 \%$ of each organic acid), P-2 (ice including $0.020 \%$ of each organic acid) and C (ice prepared from water only; control).

Table 2

Fluorescence ratio (FR) and free fatty acid (FFA) assessment* in chilled horse mackerel kept under different icing conditions**

\begin{tabular}{cccccccc}
\hline $\begin{array}{c}\text { Chilling Time } \\
\text { (days) }\end{array}$ & C & Fluorescence Ratio & & \multicolumn{3}{c}{$\begin{array}{c}\text { Free Fatty Acid } \\
\text { (g/ kg muscle) }\end{array}$} \\
& $1.86 \mathrm{~b}$ & $1.35 \mathrm{ab}$ & $0.92 \mathrm{a}$ & 0.14 & $\mathbf{C}$ & $\mathbf{P - 1}$ & $\mathbf{P}-\mathbf{2}$ \\
\hline \multirow{2}{*}{4} & $(0.15)$ & $(0.53)$ & $(0.05)$ & $(0.03)$ & $(0.03)$ & 0.16 & $(0.04)$ \\
& $2.01 \mathrm{~b}$ & $1.58 \mathrm{a}$ & $1.99 \mathrm{ab}$ & 0.20 & 0.21 & 0.21 \\
7 & $(0.11)$ & $(0.37)$ & $(0.27)$ & $(0.05)$ & $(0.07)$ & $(0.02)$ \\
& 2.64 & 2.19 & 2.39 & 0.26 & 0.28 & 0.27 \\
11 & $(0.54)$ & $(0.41)$ & $(0.57)$ & $(0.03)$ & $(0.02)$ & $(0.05)$ \\
& 2.96 & 3.37 & 2.87 & 0.33 & 0.32 & 0.32 \\
13 & $(0.28)$ & $(0.35)$ & $(0.44)$ & $(0.01)$ & $(0.04)$ & $(0.04)$ \\
\hline
\end{tabular}

* Mean values of three independent determinations (n 53 ); standard deviations are indicated in brackets.

Starting fish values: $0.92 \pm 0.08$ (FR) and $0.11 \pm 0.05$ (FFA). For each parameter and for each chilling time, mean values followed by different letters $(a, b)$ indicate significant $(p<0.05)$ differences as a result of the icing condition.

** Abbreviations of icing conditions as expressed in Table 1.

to previous research related to horse mackerel chilled storage under traditional flake ice conditions (Aubourg, 2001; Losada et al., 2005). However, as a result of endogenous enzyme activity, an important lipid hydrolysis development has already been detected in horse mackerel muscle during frozen storage (Aubourg and Ugliano, 2002; Lugasi et al., 2007).

The formation of FFA itself does not lead to nutritional losses. However, FFA presence has shown an important role in fish muscle texture changes (Sikorski and Kolakowska, 1994) and lipid oxidation enhancement (Mackie, 1993) and as being strongly related with off-odor development (Refsgaard et al., 2000). Additionally, FFA have shown to develop a bigger oxidation rate than higher molecular-weight lipid classes such as triglycerides and phospholipids as a result of providing a lower steric hindrance to the initial development of the oxidation mechanism (Labuza, 1971).

\subsection{Quality loss assessment by non-lipid chemical indexes}

During post-mortem fish storage, muscle nucleotides are known to degrade in a series of stages as a result of endogenous biochemical changes; the level of major adenine nucleotides and their related compounds have been used extensively as an index of freshness ( $\mathrm{K}$ value assessment) of fish muscle (Howgate, 2006). In the present research (Table 3), fish corresponding to all kinds of icing conditions showed a progressive $\mathrm{K}$ value increase with chilling time, in agreement with previous research where this fish species was stored under traditional icing conditions (Losada et al., 2005). However, no differences ( $p>0.05$ ) as a result of the icing system employed could be observed in the actual study. It is concluded that, under the present conditions, the presence of the organic 
Table 3

$\mathrm{K}$ value and $\mathrm{pH}$ assessment* in chilled horse mackerel kept under different icing conditions ${ }^{\star \star}$

\begin{tabular}{|c|c|c|c|c|c|c|}
\hline \multirow{2}{*}{$\begin{array}{c}\text { Chilling } \\
\text { Time (days) }\end{array}$} & \multicolumn{3}{|c|}{ K Value } & \multicolumn{3}{|c|}{$\mathrm{pH}$} \\
\hline & C & P-1 & P-2 & C & P-1 & P-2 \\
\hline 4 & $\begin{array}{l}14.00 \\
(0.99)\end{array}$ & $\begin{array}{l}15.24 \\
(0.56)\end{array}$ & $\begin{array}{l}15.00 \\
(1.20)\end{array}$ & $\begin{array}{l}6.61 \\
(0.11)\end{array}$ & $\begin{array}{c}6.49 \\
(0.10)\end{array}$ & $\begin{array}{c}6.57 \\
(0.01)\end{array}$ \\
\hline 7 & $\begin{array}{l}21.57 \\
(1.66)\end{array}$ & $\begin{array}{l}23.09 \\
(0.79)\end{array}$ & $\begin{array}{l}20.95 \\
(3.20)\end{array}$ & $\begin{array}{c}6.48 \\
(0.09)\end{array}$ & $\begin{array}{c}6.50 \\
(0.10)\end{array}$ & $\begin{array}{c}6.46 \\
(0.03)\end{array}$ \\
\hline 11 & $\begin{array}{l}37.41 \\
(2.44)\end{array}$ & $\begin{array}{l}40.94 \\
(2.22)\end{array}$ & $\begin{array}{l}39.21 \\
(1.30)\end{array}$ & $\begin{array}{c}6.96 \\
(0.13)\end{array}$ & $\begin{array}{l}6.88 \\
(0.05)\end{array}$ & $\begin{array}{c}6.86 \\
(0.24)\end{array}$ \\
\hline 13 & $\begin{array}{l}44.66 \\
(1.66) \\
\end{array}$ & $\begin{array}{l}43.81 \\
(1.22) \\
\end{array}$ & $\begin{array}{l}43.03 \\
(0.97) \\
\end{array}$ & $\begin{array}{c}7.12 \\
(0.02)\end{array}$ & $\begin{array}{l}7.15 \\
(0.07)\end{array}$ & $\begin{array}{c}7.07 \\
(0.08)\end{array}$ \\
\hline
\end{tabular}

* Mean values of three independent determinations $(n=3)$; standard deviations are indicated in brackets. Starting fish values:

$7.38 \pm 0.57$ (K value) and 6.37 $\pm 0.10(\mathrm{pH})$. No significant differences $(\mathrm{p}>0.05)$ could be observed as a result of the icing condition.

** Abbreviations of icing conditions as expressed in Table 1.

acid mixture has no effect on the muscle nucleotide degradation. On the contrary, previous research has shown a great influence of storage temperature on the $\mathrm{K}$ value when comparing traditional flake ice and slurry ice conditions (Piñeiro et al., 2004; Losada et al., 2005; Lago et al., 2010).

The $\mathrm{pH}$ value showed, with some exceptions, a progressive increase with chilling time in all fish batches (Table 3), according to previous research (Mendes, 1999; Rodríguez et al., 2005). Such increase would suggest a more intense growth of alkalinizing bacteria, leading to a higher accumulation of ammonia compounds. However, no differences $(p>0.05)$ as a result of the icing conditions employed could be observed. In spite of the fact that $\mathrm{pH}$ value is considered a dependable spoilage index, its assessment in the present research was not suitable for showing quality differences among the different kinds of fish samples under study.

\subsection{Sensory analysis}

Sensory acceptance results can be shown in Table 4. In all cases, a progressive quality decrease was detected by the panel with chilling time for all kinds of fish samples. Control fish and fish corresponding to P-1 condition have led to a shelf life time of 7 days, according to previous research related to horse mackerel kept under traditional flake ice conditions (Simeonidou et al., 1997; Aubourg, 2001). However, individuals corresponding to the highest acid content condition (P-2) were still acceptable at day 11 . As a result, a preserving effect of this kind of icing medium is concluded for the sensory attributes, so that a longer shelf life time is attained. For all kinds of fish samples, features that limited the acceptability of horse mackerel were eye appearance, external and flesh (both in raw and cooked conditions) odors and gill appearance.

According to sensory analysis results, the P-2 condition has shown a stronger preservative effect than in the case of analyzing the chemical quality indexes, including the lipid indexes. Since organic acids applied in the present research have been reported to have antimicrobial properties in addition to antioxidant ones (Erkan, 2003; Kilinc et al., 2009), an antimicrobial effect would have been likely to occur by employment of this condition, leading to a remarkable sensory quality retention.

Table 4

Evolution of sensory acceptance* in chilled horse mackerel kept under different icing conditions ${ }^{\star \star}$

\begin{tabular}{cccc}
\hline $\begin{array}{c}\text { Chilling Time } \\
\text { (days) }\end{array}$ & C & $\begin{array}{c}\text { Icing Condition } \\
\text { P-1 }\end{array}$ & P-2 \\
\hline 4 & $\mathrm{~A}^{\mathrm{b}}$ & $\mathrm{A}^{\mathrm{b}}$ & $\mathrm{E}^{\mathrm{a}}$ \\
7 & $\mathrm{~B}^{\mathrm{b}}$ & $\mathrm{A}^{\mathrm{a}}$ & $\mathrm{A}^{\mathrm{a}}$ \\
11 & $\mathrm{C}^{\mathrm{b}}$ & $\mathrm{C}^{\mathrm{b}}$ & $\mathrm{B}^{\mathrm{a}}$ \\
13 & $\mathrm{C}$ & $\mathrm{C}$ & $\mathrm{C}$ \\
\hline
\end{tabular}

* Quality categories: E (excellent), A (good), B (fair) and C (unacceptable). Starting fish was category $E$. For each chilling time, mean values followed by different superscript letters $(a, b)$ indicate significant $(p<0.05)$ differences as a result of the icing condition.

${ }^{\star \star}$ Abbreviations of icing conditions as expressed in Table 1. 


\section{FINAL REMARKS}

Assurance of both high acceptability and nutritional values of chilled seafood is currently an important challenge for fish traders and food technologists, so that commercial requirements are always related to the search for valuable and practical technologies that may provide enhancing possibilities of quality retention.

In the present research, icing systems including a mixture of natural organic acids were tested and applied during horse mackerel chilling storage. According to lipid oxidation (peroxide and TBARS formation) assessment, a slight inhibitory effect $(p<0.05)$ was concluded as a result of the presence of the acid mixture. However, no effect $(p>0.05)$ of the acid presence in the icing system could be outlined on the nucleotide degradation and the FFA formation. In addition, no differences could be concluded between $\mathrm{P}-1$ and $\mathrm{P}-2$ treatments, when analyzing the results obtained on chemical quality indexes.

P-2-treated fish showed a longer shelf life time than their counterparts belonging to $\mathrm{P}-1$ and control conditions. According to the sensory analysis results, P-2 condition has shown a stronger preservative effect than in the case of analyzing the chemical quality indexes. Since organic acids applied in the present research have been reported to have antimicrobial properties in addition to antioxidant ones (Erkan, 2003; Kilinc et al., 2009), an antimicrobial effect would have been likely to occur under this condition, so that a remarkable sensory quality retention was attained. In this sense, the surface wash caused by the melting of the ice during storage and the subsequent antioxidant and antimicrobial effects of such acids on the fish skin can be invoked as the main reasons for the lower damage development found in the acidtreated horse mackerel muscle.

Similar results had been reported before for other preservation methods such as liquid ice (Piñeiro et al., 2004; Aubourg et al., 2010), where ice melting led to the release of salt that exerted a preserving effect on fish and in experiences where a washing step including a preserving aqueous solution is applied before further refrigeration or frozen storage of the fish material (Richards et al., 1998; Erkan, 2003).

\section{ACKNOWLEDGEMENTS}

The authors thank Mr. Marcos Trigo and Mrs. Cristina Nine for their excellent technical assistance. This work was supported by the Secretaría Xeral de I+D from the Xunta de Galicia (Galicia, Spain) through the Research Project PGIDIT 10 TAL 402001PR.

\section{REFERENCES}

Ashie I, Smith J, Simpson B. 1996. Spoilage and shelflife extension of fresh fish and shellfish. Crit. Rev. Food Sci. Nutr. 36, 87-121.
Aubourg S, Álvarez V, Pena J. 2010. Lipid hydrolysis and oxidation in farmed gilthead seabream (Sparus aurata) slaughtered and chilled under different icing conditions. Grasas Aceites, 61, 183-190.

Aubourg S, Pérez-Alonso F, Gallardo J. 2004. Studies on rancidity inhibition in frozen horse mackerel (Trachurus trachurus) by citric and ascorbic acids. Eur. J. Lipid Sci. Technol. 106, 232-240.

Aubourg S, Ugliano M. 2002. Effect of brine pre-treatment on lipid stability of frozen horse mackerel (Trachurus trachurus). Eur. Food Res. Technol. 215, 91-95.

Aubourg S. 2001. Damage detection in horse mackerel (Trachurus trachurus) during chilled storage. J. Amer. Oil Chem. Soc. 78, 857-862.

Aubourg, S. 1999. Effect of lipid damages on processed fish quality. Grasas Aceites 50, 218-224.

Badii F, Howell N. 2002. Effect of antioxidants, citrate, and cryoprotectants on protein denaturation and texture of frozen cod (Gadus morhua). J. Agric. Food Chem. 50, 2053-2061.

Bligh E, Dyer W. 1959. A rapid method of total extraction and purification. Can. J. Biochem. Physiol. 37, 911-917.

Chaouqy NE, Gallardo JM, El Marrakchi A, Aubourg S. 2008. Lipid damage development in anchovy (Engraulis encrasicholus) muscle during storage under refrigerated conditions. Grasas Aceites 59, 309-315.

Chapman R, McKay J. 1949. The estimation of peroxides in fats and oils by the ferric thiocyanate method. $J$. Amer. Oil Chem. Soc. 26, 360-363.

Council Regulations. 1989. Baremo de clasificación de frescura. In: Diario Oficial de las Comunidades Europeas, no L 5/21, pp. 5-6. European Communities, Brussels, Belgium.

Erkan N. 2003. Treatment of fillets (Scomber colias and Mugil cephalus) with sodium lactate and propyl gallate: influence on shelf life and quality. Archive für Lebensmittelhygiene. 54, 60-63.

Eymard S, Jacobsen C, Baron C. 2010. Assessment of washing with antioxidant on the oxidative stability of fatty fish mince during processing and storage. J. Agric. Food Chem. 58, 6182-6189.

FAO. 2007a. Fishery statistics. Commodities. In Food and Agriculture Organization of the United Nations, Yearbook 2005, Vol. 101, pp. 134-135, 138-139, 152153, 157-158, 174-175, 178, Rome, Italy.

FAO. 2007b. Fishery statistics. Capture production. In Food and Agriculture Organization of the United Nations, Yearbook 2005, Vol. 100/1, pp. 247-248, Rome, Italy.

Giese J. 1996. Antioxidants: Tools for preventing lipid oxidation. Food Technol. 50, 73-80.

Gogus U, Bozoglu F, Yurdugul, S. 2006. Comparative effects of lactic acid, nisin, coating combined and alone applications on some postmortem quality criteria of refrigerated Sardina pilchardus. J. Food Qual. 29, 658-671.

Howgate P. 2006. A review of the kinetics of degradation of inosine monophosphate in some species of fish during chilled storage. Int. J. Food Sci. Technol. 41, 341-353.

Kilinc B, Cakli S, Dincer T, Tolasa S. 2009. Microbiological, chemical, sensory, color, and textural changes of rainbow trout fillets treated with sodium acetate, sodium lactate, sodium citrate, and stored at $4^{\circ} \mathrm{C} . \mathrm{J}$. Aquat. Food Prod. Technol. 18, 3-17.

Kim C, Hearnsberger J, Eun J. 1995. Gram-negative bacteria in refrigerated catfish fillets treated with lactic culture and lactic acid. J. Food Prot. 58, 639-643. 
Labuza T. 1971. Kinetics of lipid oxidation in foods. $C R C$ Crit. Rev. Food Technol. 2, 355-405.

Lago H, Pena J, Aubourg S. 2010. Effect of slaughtering conditions on lipid damage of chilled farmed turbot (Psetta maxima) muscle. Grasas Aceites, 61, 312-320.

Losada V, Piñeiro C, Barros-Velázquez J, Aubourg S. 2005. Inhibition of chemical changes related to freshness loss during storage of horse mackerel (Trachurus trachurus) in slurry ice. Food Chem. 93, 619-625.

Lowry R, Tinsley I. 1976. Rapid colorimetric determination of free fatty acids. J. Amer. Oil Chem. Soc. 53, 470-472.

Lugasi A, Losada V, Hóvári J, Lebovics V, Jakóczi I, Aubourg S. 2007. Effect of pre-soaking whole pelagic fish in a plant extract on sensory and biochemical changes during subsequent frozen storage. Food Sci. Technol. 40, 930-936.

Mackie I. 1993. The effects of freezing on flesh proteins. Food Rev. Internat. 9, 575-610.

Madrid A, Madrid J, Madrid R. 1994. Chilling, freezing and ultra-freezing of fish and derivates in Madrid A (Ed.) Technology of fish and its derivatives, pp. 45103. AMV Ediciones y Mundi-Prensa Libros, S. A., Madrid, Spain.

Mendes R, Alves Silva H, Nunes ML, Abecassis Empis J. 2005. Effect of low-dose irradiation and refrigeration on the microflora, sensory characteristics and biogenic amines of Atlantic horse mackerel (Trachurus trachurus). Eur. Food Res. Technol. 221, 329-335.

Mendes R. 1999. Changes in biogenic amines of major Portuguese bluefish species during storage at different temperatures. J. Food Biochem. 23, 33-43.

Metin S, Erkan N, Varlik C, Aran N. 2001. Extension of shelf life of chub mackerel (Scomber japonicus Houttuyn 1780) treated with lactic acid. Eur. Food Res. Technol. 213, 174-177.

Olafsdóttir G, Martinsdóttir E, Oehlenschläger J, Dalgaard P, Jensen B, Undeland I, Mackie I, Henehan G, Nielsen J, Nilsen H. 1997. Methods to evaluate fish freshness in research and industry. Trends Food Sci. Technol. 8, 258-265.

Ozen B, Floros J. 2001. Effects of emerging food processing techniques on the packaging materials. Trends Food Sci. Technol. 12, 60-67.

Pazos M, Alonso A, Sánchez I, Medina I. 2008. Hydroxytyrosol prevents oxidative deterioration in foodstuffs rich in fish lipids. J. Agric. Food Chem. 56, 3334-3340.

Piñeiro C, Barros-Velázquez J, Aubourg S. 2004. Effects of newer slurry ice systems on the quality of aquatic food products: a comparative review versus flake-ice chilling methods. Trends Food Sci. Technol. 15, 575-582.

Pourashouri P, Shabanpour B, Aubourg S, Daghigh Rohi $J$, Shabani A. 2009. An investigation of rancidity inhibition during storage of Wels catfish (Silurus glanis) fillets by previous ascorbic and citric acid treatment. Int. J. Food Sci. Technol. 44, 1503-1509.

Refsgaard H, Brockhoff P, Jensen B. 2000. Free polyunsaturated fatty acids cause taste deterioration of salmon during frozen storage. J. Agric. Food Chem. 48, 3280-3285.
Richards M, Kelleher S, Hultin H. 1998. Effect of washing with or without antioxidants on quality retention of mackerel fillets during refrigerated and frozen storage. J. Agric. Food Chem. 46, 4363-4371.

Rodríguez O, Losada V, Aubourg S, Barros-Velázquez J. 2005. Sensory, microbial and chemical effects of a slurry ice system on horse mackerel (Trachurus trachurus). J. Sci. Food Agric. 85, 235-242.

Ryder J. 1985. Determination of adenosine triphosphate and its breakdown products in fish muscle by high performance liquid chromatography. J. Agric. Food Chem. 33, 678-680.

Sallam KI. 2007. Antimicrobial and antioxidant effects of sodium acetate, sodium lactate, and sodium citrate in refrigerated sliced salmon. Food Control, 18, 566575.

Sánchez-Alonso I, Jiménez-Escrig A, Saura-Calixto F, Borderías AJ. 2007. Effect of grape antioxidant dietary fibre on the prevention of lipid oxidation in minced fish: Evaluation by different methodologies. Food Chem. 101, 372-378.

Shigemura $\mathrm{Y}$, Ando M, Tsukamasa $\mathrm{Y}$, Makinodan $\mathrm{Y}$, Kawai T. 2003. Correlation of type $V$ collagen content with post-mortem softening of fish meat during chilled storage. Fish. Sci. 69, 842-848.

Sikorski Z, Kolakowska A. 1994. Changes in protein in frozen stored fish in Sikorski Z, Sun Pan B, Shahidi F (Eds.) Seafood proteins, pp. 99-112. Chapman and Hall, New York, USA.

Simeonidou S, Govaris A, Vareltzis K. 1997. Effect of frozen storage on the quality of whole fish and fillets of horse mackerel (Trachurus trachurus) and Mediterranean hake (Merluccius mediterranean). $Z$. Lebensm. Unters. Forsch. 204, 405-410.

Sivertsvik M, Jeksrud W, Rosnes T. 2002. A review of modified atmosphere packaging of fish and fishery products - significance of microbial growth, activities and safety. Int. J. Food Sci. Technol. 37, 107-127.

Slattery S, Forrest A. 2006. Evaluation of three storage systems used for chilling and holding swordfish. J. Aquat. Food Prod. Technol. 15, 53-74.

Smith J, Hardy R, McDonald I, Templeton J. 1980. The storage of herring (Clupea harengus) in ice, refrigerated sea water and at ambient temperature. Chemical and sensory assessment. J. Sci. Food Agric. 31, 375-385.

Toledo-Flores L, Zall R. 1992. Methods for extending the storage life of fresh tropical fish in Flick G, Martin R (Eds.) Advances in Seafood Biochemistry, pp. 233243. Technomic Publishing, Lancaster, PA, USA.

Vyncke W. 1970. Direct determination of the thiobarbituric acid value in trichloracetic acid extracts of fish as a measure of oxidative rancidity. Fette Seifen Anstrichm. 72, 1084-1087.

Whittle K, Hardy R, Hobbs G. 1990. Chilled fish and fishery products in Gormley T. (Ed.) Chilled foods: The state of the art, pp. 87-116. Elsevier Applied Science, New York, USA.

Recibido: $11 / 3 / 11$ Aceptado: $12 / 4 / 11$ 